\title{
Divergent Interpretations and Inter-Organizational Relations of Halal Product Guarantee Policy in Indonesia
}

\author{
Agus Iswanto ${ }^{1}$, Koeswinarno $^{2}$ \\ ${ }^{1}$ Corresponding Author. Office of Religious and Research, Semarang, Religious Research Development and \\ Training Agency, Ministry of Religious Affairsn(email: agus.iswanto83@gmail.com) \\ ${ }^{2}$ Center for Research and Development of Religious Guidance and Services, Religious Research Development and \\ Training, Ministry of Religious Affairs (email: koeswinarnowirjosoepono@gmail.com)
}

\begin{abstract}
The emergence of the issue of halal products, both in the form of food and services, has also led to competition regarding the certification of halal products. Studies on competition between certification bodies have been carried out, but these studies do not focus on the competition that occurs in Southeast Asian countries, including Indonesia which is a big market for the halal industry. In Indonesia, the implementation of the regulation of Halal Product Guarantee (HPG) in Law No. 332014 still raises problems, including the related issue of inter-organizational relations. This article discusses the relations between organizations based on the interpretation of each party related to the Halal Product Guarantee policy, and the consequences arising from it. This article used new institutional theory, and a semiotics approach as analysis of verbal signs and gestures raised by each of the parties. This article argued that the interpretations of each organizational actor towards the new halal certification policy in Indonesia are driven by different institutional reasons/logics, resulting in contradictions, even conflicts related to the relationship between organizations implementing the policy. The difference in meaning, especially in the connotative meaning, shows the difference in institutional logic. Thus, there is a divergence in meaning. Therefore, it is important to equate significance (meaning/interpretation) to each of the institutions related to Halal Product Guarantee in order to realize the implementation of the regulations properly.
\end{abstract}

\section{Keywords:}

halal certification; organizational relation; regulation interpretation; institutional semiotics

\section{Introduction}

Since the mid-1990s, the emergence of the issue of halal products, both in the form of food and services, has also led to competition regarding the certification of halal products. Every certification body wants to be seen as "more halal" than other certifiers. This competition has been going on for more than two decades in all continents, mostly in industrialized countries without Muslim traditions, and also in several Muslim exporting countries, mostly in Southeast Asia (BergeaudBlackler, 2015). Studies on competition between certification bodies have been carried out, but these studies do not focus on the competition that occurs in Southeast Asian countries, because it is considered that the institutions that handle halal certification in these countries are public institutions that have been appointed by the state, while in other countries where Muslims are a minority it is carried out by private institutions (Bergeaud-Blackler, 2015). In addition, comparative studies on halal certification bodies (Latif, Mohamed, Sharifuddin, Abdullah, \& Ismail, 2014) have not analyzed many halal certification bodies in Indonesia, especially after the issuance of new regulations on halal guarantee in 2014. 
Law No. 33 of 2014 concerning Halal Product Guarantee was implemented in Indonesia on October 17, 2019. However, the "authority transfer" from LPPOM MUI to BPJPH has not been fully completed (Focus Group Discussion on BPJPH Business Strategy Plan prepared by the Center for Religious Guidance and Service Guidance and Services Religious in August 2019). The real problem is a set of meanings that are not easily revealed in the rivalry, because each party stands with the "truth" that was built. The writer's meeting with the Chairperson of a provincial LPPOM shows that there are 'things' not easily resolved in formal forums. "We do not have the authority to provide data, because we have submitted all data to the center (read: Central LPPOM)" (interview with the Chairperson of the Provincial LPPOM X, August 2019).

Signs of rivalry reappeared after a series of meetings, both informally and formally through discussion forums with BPJPH officials at various levels, which showed that the "MUI relationship with BPJPH" was difficult to comprehend. Law Number 33 Year 2014 and Government Regulation Number 31 Year 2019 have indeed set the roles of each party in the Halal Product Guarantee (HPG), but they certainly have a "meaning" respectively for both parties. Even NU has firmly rejected the halal product guarantee law allegedly causing a monopoly (NU Online, 2020). Besides, there are several omnibus laws of articles in the Act. No. 33 of 2014 due to the issuance of employment copyright law (Saputra, 2020).

This article will explore the meaning behind the 'phenomenon' of interorganizational relations issues related to halal product guarantee. The issue of this relationship is trying to be traced through the interpretation of each of the parties over the regulations, namely Law No. 33 of 2014 and PP No. 31 of 2019. Understanding the style of language between those in BPJPH and those in MUI becomes very important, because in the future these two large organizations will continue to interact. Although searching for meaning is a subjective problem, seeing what is written and what is implied is interesting in the study of language, especially if it is related to the expression of the meaning of policy regulation.

Many studies on halal policy in Indonesia have been carried out (Afroniyati, 2014; Akim, Konety, Purnama, \& Korina, 2019; Asa, 2019), but there are still gaps in knowledge about the interpretation of policies issued and their implications for relations between organizations related to these policies. Linking to institutional theory, the current issues for institutional theorists are about institutional complexity and contradiction, as well as organizational responses to institutional pressures (Greenwood, Díaz, Li, \& Lorente, 2010; Greenwood, Raynard, Kodeih, Micelotta, \& Lounsbury, 2011; Pache \& Santos, 2010; Reay \& Hinings, 2009; Thomann, Lieberherr, \& Ingold, 2016). However, the study of halal policy interpretation and its implications for inter-organizational relations based on the perspective of institutional theory is still limited. This research fills the gap by applying an new institutional theory framework (institutional logic) (P. Thornton, Ocasio, \& Lounsbury, 2015) assisted by a semiotic approach. The semiotic approach and new institutional theory, known as institutional semiotics (Arnold, Kozinets, \& Handelman, 2001), can help understand the divergence of interpretations of each organization on the halal product guarantee policy.

Based on the background of the problem, the formulation of the problems proposed in this research are: how certain institutional logic (e.g. Religion, business, profession) influences organizational actors from BPJPH, MUI, universities, and firms interpret halal product guarantee policy (government regulation)?; how is divergent interpretation related to inter organizational relation involved in halal 
product guarantee? With the formulation, this article argues that the interpretations of each organizational actor towards the new halal product policy in Indonesia are driven by different institutional logics, resulting in contradictions, even conflicts related to the relationship between organizations implementing the policy.

Thus, this article fills a gap in knowledge about certification body competition that occurs in line with the fast-growing demand for the halal market in the world with the case of Indonesia being one of the largest halal markets. In addition, by looking at the language style of this competition, this study contributes to the semiotic approach and institutional logic that can be used in seeing the rivalry of certification bodies in Indonesia.

\section{Literature review}

There were studies concerning the development of halal regulations (Akim et al., 2019; Asa, 2019), its implementation (Anwar, Fahrullah, \& Ridlwan, 2018; Nafis, 2019; Othman, Shaarani, \& Bahron, 2016; Zulkifli \& Mochammad Sahid, 2018), and its organizations (Afroniyati, 2014; Faidah, 2017), as well as problems in certification (Prabowo, Rahman, Rahman, \& Samah, 2015; Viverita \& Kusumastuti, 2017). Except Afroniyati and Faidah's study, the studies have not revealed the inter-organizational relations after the enactment of the Act No. 33 of 2014 and its derivative regulations. Akim et al.'s study has shown the advantages of transferring halal certification into the state, although it must immediately prepare all the necessary infrastructure, but it has not revealed the "conflict" in the organizational transformation. The other studies (Wahyudi, Asikin, \& Haq, 2020) have actually proposed some weaknesses of the latest regulations on halal certification in Indonesia, but have not yet explained the root causes of these weaknesses, which according to this article are inter-institutional relations issues.
The tension between MUI and the government in halal certification has actually been pointed out by Hosen (2012). Hosen has written that halal fatwas, audits, and certifications cannot be in the hands of one organization. This will create a monopoly as also analyzed by another study (Lindsey, 2012), and potentially provide an opportunity for companies or business people who are not responsible for negotiating prices and costs in submitting halal certification (Hosen, 2012, p. 16). Hosen also has proposed that other organizations or institutions must also be able to issue halal certificates, to avoid monopolies and reduce costs. It is not appropriate for MUI to be involved in the business side of halal certification. They must maintain their initial role in providing fatwas and guidance, like NU and Muhammadiyah.

Halal certification by MUI, especially before promulgation in clear regulations and since the emergence of the Halal Product Guarantee draft laws, was allegedly not only religiously charged but also a "commercial commodification" (economy) (Afroniyati, 2014). In line with the two studies above, another study also states that in Indonesia, MUI - as a social organization - monopolizes halal certification (Othman et al., 2016). The same was proposed by Faidah (2017) for the case of halal product certification in general, and Suharko et al. (2018) for the context of halal tourism products, precisely the relationship between the state and the community (community organizations), namely MUI. However, the studies did not discuss the views of each organization related to the halal certification after the latest regulation was published (Law No. 33 of 2014). Previously LPPOM MUI was the only authoritative institution issuing halal certification, but now it has become the government's authority. The transformation of this role is still new, meaning regulatory transition, from the old regulation to the new one, so that tensions might arise, and it impacts 
on changes in authority. This research attempts to trace these problems.

The difference in interpretation of regulation, in the light of the new institutional theory, is due to different institutional logics (Bertels \& Lawrence, 2016; Greenwood et al., 2010; Reay \& Hinings, 2009; P. Thornton et al., 2015), which causes divergence in interpretation. This divergence in interpretation causes contradiction and conflict between organizations that implement halal product policies, so that policy implementation does not work. To see the differences in interpretation and response, this article uses a semiotic theoretical framework which shows "language stye" related to power relationships (Wareing, 2004).

Semiotics and symbol studies as a theoretical framework in analyzing sociocultural issues, including in public policy, public administration, and corporate culture issues, have been used, although rarely in Indonesia (Atkinson, 2018, 2019; Bondestam, 2004; Fiol, 1989; Garrick \& Pendergast, 2014; Goodsell, 1977; Kurland \& Aleci, 2015). Semiotics has also been used to research institutional semiotics which focuses on Jakobson's semiotics (Arnold et al., 2001). This research does not use Jakobson semiotics, but Barthes semiotics.

The use of Barthesian semiotics has also been exemplified by a study of the Regional Aspirations Fund (Pasoloran, 2016). From some public policy research experiences using a semiotic approach, this research sought to understand the meanings from institutions related to the discourse of Halal Product Guarantee (HPG) after the issuance of the Act. No. 33 of 2014 and PP. No. 31 of 2019. The meanings arose because of the process of interpretation ("significance" in the term of semiotics) of each institution related to Halal Product Guarantee.

The semiotic proposition used to understand the problem of studying relations between organizations is the similarity of significance which means there is the same understanding of the connotative meaning of Halal Product Guarantee regulations, so that it will bring about sucessful implementation of regulations as well as inter-institutional relations that handle these regulations. At the same time, the similarity in understanding is the similarity of institutional logic (based in institutional theory) in each organization related to halal certification.

\section{Methods}

This research was conducted through a qualitative approach by taking the case of halal certification regulations in Indonesia on the grounds that, Indonesia is one of the countries with the largest Muslim majority in the world, of course this has implications for the large demand for halal products, and therefore makes a lot of requests for halal certification services. Because the problem studied is about the subjective meanings of each organizational actor, the approach chosen is qualitative.

The research was conducted in four steps. The first is interview which was more directed at the verbal observations of the subjects including their expressions or gestures when they were speaking verbally. Interview data were the main source of this research, because the researcher could read the data with a semiotic framework. Informants are selected purposively based on competence in organizations related to halal product policies, such as MUI halal auditors, MUI halal certification managers (LPPOM MUI), halal certification service officers at the regional Ministry of Religion offices, Halal Inspection Agency (LPH) from universities, and entrepreneurs/firms. From each of these organizations at least one person we interviewed. Informants were selected and determined to represent each of the institutions involved in HPG based on the longest and most intensively involved persons in HPG activities or halal certification.

The interviews were conducted by asking questions focusing on inter-organization 
relations problems. Of course, these questions were only used to begin the interviews. Furthermore, the researcher could explore practically with a variety of other sentences to capture the meaning behind what was said by the informants. The interviews were probing, which included exploring continuously to get answers believed by the informants.

Interviews were conducted simultaneously with close attention to the movements, or gestures of each informant to get a complete understanding of each party. To avoid conflict and maintain research ethics, location and names of informants were pseudonyms. We only show the position of informants in the organization as previously described. The same was true for non-LPPOM LPH organizations. Knowing which regions submitted judicial reviews and which did not could be the only clue of the informants and the location for this research.

The second, to obtain data on HPG discourse in general, this research relied on document studies and literature studies to see the discourse that appeared in the media about inter-organizational relations related to HPG. This discourse that appeared in this media was important as preliminary data before it was clarified by data directly obtained by researchers. This media source was certainly a secondary source, but it still needed to be considered in understanding the journey of inter-agency relations after the Act. No. 30 of 2019 and after it took effect on October 17.

The third, document study was also conducted on a series of regulations issued related to HPG. This study also tried to present a general view of HPG and halal certification as stipulated in the regulation. The researchers attempted to read regulatory texts, and then they were tested with a series of interviews to obtain meaningful data conducted by institutions related to HPG. To read the regulations was limited to the effort to present "denotative meaning" about HPG regulation.
This reading was limited to aspects of interinstitutional relations in HPG.

With these data, the researchers could finally interpret the meaning of the second level or significance in semiotic analysis. Therefore, semiotics is a way to understand the data that has been obtained. Semiotics or semiology is the science of signs (henceforth, taking into account of the popularity of the terms used, this research used the word "semiotics"). The "sign" itself is something that refers to something else. For example, say A refers to A1 and so on. However, the actual study or analysis of semiotics is not about a study of A, but a study of the relationship between $\mathrm{A}$ and A1 (Christomy, 2010). There are several forms of signs, and those relevant to this research are the ones in the form of activities and performances (Berger, 2015, p. 37). "Something that we do will mark a big decision," wrote Berger. "We give a lot of signs with body language, gestures that we do," continued Berger. When explaining the shape of this sign, Berger cites the analysis of Roland Barthes (1972, pp. 26-29), one of the leading figures in the Sausserian semiotics (structuralism semiotic which shows binary opposition of the language; surface and deep structure), when describing a scene in a film. He has explained that sweating is a sign of one's inner feelings. Sweating can indicate someone who is afraid. This means that gestures, physical appearance, or changes in the body mark a particular thought. This is useful when interpreting various body movements or gestures of a person.

The most important thing in the semiotics analysis is about the analysis of "significance" (Sunardi, 2004). This term is one that is often used in semiotic analysis. Significance is a process of meaning of a sign. However, significance does not mean "meaning" in itself. A sign, in the process of significance, has meaning if it has a relationship with another sign, whether it is an associative/ paradigmatic, syntagmatic, symbolic, or 
connotative relationship. According to Barthes's semiotic view, the analysis of the significance of the sign must always reach the meaning at the second level. With a little modification, this research means significance as "meaning that contains value for those who give meaning to signs" namely the meaning that is considered important and valuable for the giver of meaning, or in Barthes's term called connotative (Barthes, 1972, p. 117, 1986, p. 39; Hoed, 2010, pp. 52-53). Therefore, based on the explanation, when getting verbal signs and gestures, this research did not stop at the primary or first meaning system, but continued on the secondary or second meaning system. Secondary meaning is connotative meaning given by a person or community.

Then where does the semiotic limit work in "investigating the meaning" behind the sign? The answer to this can refer to Umberto Eco's statement (Christomy, 2010, p. 142), which is "interpretants are testable and describable correspondent associated by public agreement to another sign." An interpretation of the sign must still be tested by the public agreement on the other signs. This was demonstrated by Barthes (1992). The context can be searched from various sources, such as mass media, regulations, and some previous studies.

Through the Barthesian semiotic theory framework, this research has considered that harmonious relations between organizations related to HPG will be realized if there is a similar meaning (significance) to HPG discourse as stated in the published regulations. If each of the institutions has a different significance, this will disrupt inter-organizational relations, so that it will eventually disrupt public policies and services in the community. This research sought to read the various significance arising in each of the institutions involved in HPG.

To operationalize Barthes semiotic method, first we have read the regulation on halal product guarantees issued by the government, we interpret denotative and connotative meaning, then compared it with the meanings interpreted by the informants (i.e. for halal auditor). The meanings issued by the informants are also compared with all gestures that appear when giving statements of meaning. The meanings issued by the informants that are not mentioned in the regulation are then called the secondary meaning, or the meaning of significance.

\section{Results}

\section{Meanings of Law. 33 of 2014 and PP. 312019}

Let us present a summary of the meanings that appear in the interpretation of the Halal Product Guarantee regulations issued by the government (No. 33 of 2014 and PP. 31 2019). This data is based on the results of interviews, gesture observations, and document studies of organizations related to the implementation of Halal Product Guarantee.

\section{- Denotative Meaning}

In denotative JPH regulation (Law No. 33 of 201), as mentioned in article 3, is "providing comfort, security, safety, and certainty of the availability of Halal Products for the public in consuming and using products." In addition, the administration of JPH also aims to "increase added value for businesses to produce and sell halal products". On several interviews, the regulation is mandatory.

\section{- Connotative Meaning}

The statement above is straightforward about the denotative meaning of the Act. 33 of 2014 and its derivatives. Furthermore, to carry out these objectives BPJPH was founded as an institution that organizes halal product guarantees.

Thus, BPJPH has power in JPH. Therefore, connotatively $\mathrm{BPJPH}$ is a representation of state power over the halal of a product. The meaning of this "state power" connotatively is also shown in article 4 which states that: "products that enter, circulate, and trade within the 
Table 1.

Summary of the meanings in the interpretation of the Halal Product Guarantee Regulation from Organization Actors

\begin{tabular}{lllll}
\hline $\begin{array}{l}\text { Organizational } \\
\text { Elements }\end{array}$ & $\begin{array}{l}\text { LPH (Non } \\
\text { LPPOM MUI/ } \\
\text { Universities }\end{array}$ & $\begin{array}{l}\text { Halal Auditor } \\
\text { (LPPOM MUI) }\end{array}$ & $\begin{array}{l}\text { Halal Auditor Non } \\
\text { LPPOM MUI }\end{array}$ & $\begin{array}{l}\text { Ministry of Religion } \\
\text { Regional Representative / } \\
\text { BPJPH }\end{array}$ \\
\hline $\begin{array}{l}\text { Denotative Meaning } \\
\text { Connotative meaning }\end{array}$ & $\begin{array}{l}\text { Mandatory } \\
\text { More orders for } \\
\text { halal certification } \\
\text { services }\end{array}$ & $\begin{array}{l}\text { Mandatory } \\
\text { Increasing }\end{array}$ & $\begin{array}{l}\text { Mandatory } \\
\text { workload } \\
\text { Increasing the } \\
\text { auditor's economic } \\
\text { income }\end{array}$ & $\begin{array}{l}\text { Mandatory } \\
\text { Conflict of economic } \\
\text { interests between the } \\
\text { status quo and newly } \\
\text { institutionalized } \\
\text { organizations }\end{array}$ \\
\hline
\end{tabular}

Source: Obtained from primary data

territory of Indonesia must be halal-certified." The mandate here suggests a state intervention on a food, drink, or other products consumed by Indonesian people. Any things that involve state intervention on a product are those that are "public", regardless of any belief, but in this regulation, the state intervenes in a matter that is believed by a group of people on a product. In other words, in a democratic perspective, the state has intervened in the "private sphere", namely the confidence of its citizens of an item.

But, based on an interview and gesture observation with an official at the Ministry of Religion in Province A (interview 23 October 2019) and an LPH chairman from university B in Province A (interview 25 October 2019), it revealed such a competition, even a clash between these powers. "LPPOM seems unwilling, because inevitably it will lose income. For example, when I visited the UMKM Office, almost all of them there were auditors of LPPOM. If we are in charge (LPH other than LPPOM), "they will lose their revenue." That was stated in one interview (interview with the head of LPH at B university B in Province A, 25 October 2019). An official at the Province of Religion Ministry A also said that "There may be a sense of concern. When the government guarantees halal products later, they will no longer be involved" (interview with an echelon III official at the Provincial Office of the Ministry of Religion, October 23, 2019).
- JPH Regulation Meaning for Halal Auditors As explained before, because it is mandatory to do, the more halal certifications are required, the more LPHs are needed. Each province will establish many LPHs, and this - as connotative meaning - will become "economic land" for LPH managers other than LPPOMMUI.

Besides LPH, there are auditors whose meaning needs to be seen. An auditor in the Act. No. 33 of 2014 is mentioned as a person who has the ability to carry out product halal inspection. The auditor is tasked with examining and reviewing the materials used, examining and reviewing the product processing, examining and reviewing the slaughtering system, examining the location of the product, examining equipment, production space, and storage, checking the distribution and presentation of the product, examining the halal guarantee system of business actors, and reporting examination results / and / or testing to LPH. Thus, the auditor is the "spearhead" of LPH. The auditor determines the halal of a product.

The auditors, especially those in LPPOMMUI that have been running halal product audit for a long time, will certainly have more work along with more income. This was revealed in an interview with one of the LPPOM-MUI auditors (interview with LPPOM-MUI auditor in Province A, 24 October 2019). This is not 
despicable because it is in accordance with the "law" of professionalism, where a profession will determine the "price" that must be given. Therefore, actually there is no problem for the auditor with the new JPH regulation, and even now the auditors are free to choose which LPH they will work for, even though the LPPOMMUI auditors in Province A have signed an agreement to continue working as LPPOMMUI auditors.

\section{Discussion}

\section{Divergent Interpretation, Power Relation, and} Regulation Liminality

Based on theoretical frameworks, the results of this study show that the difference in meaning, especially in the connotative meaning, shows the difference in institutional logic used by organizational actors in responding to regulatory changes (Greenwood et al., 2010; P. H. Thornton, Ocasio, \& Lounsbury, 2015). This is because the context and norms used in responding to these regulatory changes are different, there are only religious norms (guarantee of halal products as a religious obligation), political norms (guarantee of halal products as a guarantee of public power over their beliefs), and economic norms (guaranteed halal products increase economic income). Furthermore, we will show that the divergence in interpretation is also due to the political and personal power relations which have their respective institutional logics.

HPG regulation is a "language style" representing certain powers. According to this illustration of power and language (Wareing, 2004), JPH regulation in the Act. No. 33 of 2014 is the political power that regulates the halal product, but this political power does not lead to a closed power. With the "language of political power," this regulation also opens space for "personal power" articulated in the "language" of LPHs and business people. Thus, in other words the regulation of the Act. No. 33 of 2014 is a negotiation between political power and personal power, although the one that has the most power is political power.

Political (state) power over halal products at a glance has a negative connotation meaning, namely excessive state control over halal products consumed. However, the negative connotation about power is only a "myth" (not real meaning). In the concept of political ethics, the political power of the state about HPG is not a form of totalitarianism (the state mainly regulates everything, while the society follows all state commands). However, HPG regulations as a form of state political power in the context of the state's duty are to: (1) provide protection to its citizens; (2) support or provide various community life services in the social, economic and religious fields (Magnis-Suseno, 2019, p. 404).

The state's duty in providing protection to its citizens in the context of HPG regulations is related to the protection of the state against the convenience of its citizens in consuming products, while, its duty to provide various community life services in the context of HPG is related to state services to guarantee its citizens in carrying out their religious teachings. However, in relation to the latter it does not mean the reunification of the state, but religion is an essential element in the welfare of religion, so the state is obliged to guarantee social conditions so that religions can exist and develop while respecting the freedom to practice the religions (Magnis-Suseno, 2019, pp. 404, 468).

Regulation as a sign of political power is used to show public confidence about the guaranteed implementation of the teachings of its citizens (positioning) (Hoed, 2011, p. 176). Thus, BPJPH occupies a position as a representation of state power over the halal status of products, although this position leads to a positive direction. This requires BPJPH to play the role of attorney for the implementation of a good halal product guarantee.

Before the issuance and promulgation of the HPG Law, the executor of the halal product 
guarantee was LPPOM MUI. LPPOM MUI was the one that "mastered" the certification of halal products together with the MUI Fatwa Commission in one institution. From registration to the issuance of halal certificates, LPPOM had many roles. BPOM also took a part to issue a halal label based on the recommendation of the MUI and LPPOM fatwa commission (see figures 1 and 2 above). Thus, practically LPPOM under MUI was the one mainly to play roles, and MUI is a social organization. Thus, it was a personal / community power.

From the two interviews and gesture observation, it can be interpreted that there is actually a competition and clash between state power (political power) and personal power. LPPOM as the executor of the pre-law halal product guarantee. No. 33 of 2014 feels it will "lose revenue," because the certification process is no longer carried out by LPPOM. This was reinforced when asked about halal certification financing before the latest regulations. Some informants who were interviewed, always said that it was not clear, that the halal auditor at LPPOM in Province A did not really know how much the costs were incurred by business actors to process halal certification. The auditor only knows the cost of accommodation and transportation when auditing halal products (interview with LPPOM-MUI halal auditor Province A, 24 October 2019).

Conflicts between these "powers" become prevalent in the transition period of "power," especially since the new power system cannot really be implemented. In the transition period, the situation of "liminality" becomes commonplace. This term is commonly used in social change by anthropologists. The concept of liminality, from the Latin word for 'threshold', implies all kinds of conditions "in between". This concept is related to Victor Turner's work, which is an extension of Arnold van Gennep's original ideas (Rapport \& Overing, 2000). There is an "abnormality" in a transitional "rite," so there must be an adjustment that is even preceded by a "collision" and the conflict in it before finally entering the normal stage.

The abnormality is indicated by the unpreparedness of the new institution (BPJPH) in serving halal certification, while the demand is increasing. Moreover, there is a kind of disappointment, even rejection from the ruling system in the past. In the view of sociology (Soekanto, 1989, p. 320), change will result in disorganization due to the "abnormality" of the order, but the disorganization will form a reorganization or reintegration into the normal phase. The reorganization phase will succeed if it increases the effectiveness of the service so that it will reduce rejection. According to a semiotic perspective, the decline in rejection occurs when there is an "understanding" or similarity of "significance" (meaning) to regulation. As long as the significance that emerges from LPPOM is "revenue loss," of course conflict will continue because there is a vested interest in it.

If significant disagreements about regulations continue to occur, organizations in the HPG system are not ready to serve the public who are clearly implementing the regulations. This will further increase public distrust of government performance, so that it will lead to a failure to comply with regulations (Widaningrum, 2017, p. 11). Therefore, the same significance is required to form an agreement to run a regulation normally.

Nevertheless, to reach a normal regulation, there are certainly compromises in order to emerge mutual similarity in significance or meaning. In the transition period, since the implementation of halal product assurance certification was switched to $\mathrm{BPJPH}$ as announced on October 17, many submissions for halal certification have been delayed due to BPJPH's "unpreparedness" in practice in the field. Thus, business operators will wonder and be disappointed with the new regulations which in fact slow down halal guarantee services. Meanwhile, other 
instruments in HPG, such as LPH and auditors are not really ready. There is only one LPH and its auditors ready with the established system, namely LPPOM-MUI.

Finally, a joint agreement between $\mathrm{BPJPH}, \mathrm{MUI}$, and LPPOM-MUI regarding halal certification services was decided on November 20, 2019. The agreement stated that the for the applications of halal certification through BPJPH already manually done and complete, cover letters were made to be forwarded to LPPOMMUI as LPH for halal examination or testing. The complete halal certification documents from the business actor were uploaded by BPJPH officers to LPPOM Online Certification (CEROL SS-2300). Although this was done during the transition period, it was considered a compromise. It means a change, where something long ago is not left completely quickly and immediately, because if it is done, the "clash" between interests will always happen, leading to the loss of the business community.

At first "agreement" - or called a "win-win solution" - shows the "victory" of LPPOM-MUI because it is still "in power" with the old system. However, if we see the connotative meaning, which is a substantive meaning of the HPG regulation, that the state power over halal product arises because of consideration to guarantee citizens to implement their religious teachings, including the teachings on halal products in Islam, the act of agreement wins business players and consumers. It has a negative side about politics and economics in the halal product guarantee system as some of the previous researchers concluded because this agreement is tantamount to giving the LPPOM-MUI full power as LPH in the transition period in order to maintain political-economic "stability" and inter-organizational relations.

\section{Conclusion}

This article concludes that the interpretations of each organizational actor towards the new halal product policy in
Indonesia are driven by different institutional logics, resulting in contradictions, even conflicts related to the relationship between organizations implementing the policy. The difference in meaning, especially in the connotative meaning, shows the difference in institutional logic used by organizational actors in responding to regulatory changes. This is because the context and norms used in responding to these regulatory changes are different. There are two norms that play the largest role in the interpretation of halal guarantee regulations, namely political and economic norms. Political norms are related to the power relations between the state and society, while economic norms are related to the economic benefits that are obtained from the enactment of regulations. This difference in institutional logic (institutional norms) causes conflict of relations between organizations. Therefore, all organizations and infrastructure need to be prepared properly and quickly. Besides, most importantly "significance" (meaning) needs to be equated in each organization dealing with HPG to realize the substantive-connotative meaning of HPG regulation.

However, this study suffers from several limitations. This article does not explore the latest development of several agreements between organizations. The research also does not cover all organizations in all regions of Indonesia, so it is not sufficient to comprehensively show the conflicts that arise due to different interpretations of the new regulations regarding HPG. In addition, this research has not sufficiently explored data from the perspective of firms that require halal certification services. Hence, these deficiencies can be continued in the further research agenda.

\section{References}

Afroniyati, L. (2014). Analisis Ekonomi Politik Sertifikasi Halal Oleh Majelis Ulama Indonesia. JKAP: Jurnal Kebijakan $\mathcal{E}$ 
Administrasi Publik, 18(1), 37-52. https:// doi.org/https://doi.org/10.22146/jkap.6870 Akim, A., Konety, N., Purnama, C., \& Korina, L. C. (2019). The Shifting of Halal Certification System in Indonesia: From Society-Centric To State-Centric. MIMBAR : Jurnal Sosial Dan Pembangunan, 35(1), 115-126. https:// doi.org/10.29313/mimbar.v35i1.4223

Anwar, M. K., Fahrullah, A., \& Ridlwan, A. A. (2018). The Problems of Halal Certification for Food Industry in Indonesia. International Journal of Civil Engineering and Technology, 9(8), 16251632. Retrieved from http://www.iaeme. com/ijciet/issues.asp?JType=IJCIET\&VTy pe $=9 \&$ IType $=8 \% 0 \mathrm{~A} 1$.

Arnold, S. J., Kozinets, R. V., \& Handelman, J. M. (2001). Hometown ideology and retailer legitimation: The institutional semiotics of Wal-Mart flyers. Journal of Retailing, 77(2), 243-271. https://doi. org/10.1016/S0022-4359(01)00046-X

Asa, R. S. (2019). An Overview of the Developments of Halal Certification Laws in Malaysia, Singapore, Brunei and Indonesia. Jurnal Syariah, 27(1), 179.

Atkinson, C. L. (2018). Semiotic Theory and Public Administration. In A. Farazmand (Ed.), Global Encyclopedia of Public Administration, Public Policy, and Governance (pp. 1-6). Cham: Springer International Publishing. https://doi. org/10.1007/978-3-319-31816-5

Atkinson, C. L. (2019). Semiotic Analysis and Public Policy. Semiotic Analysis and Public Policy. New YOrk and London: Routledge. https://doi.org/10.4324/9781351205993-2

Barthes, R. (1972). Mythologies (25th print). New York: The Noonday Press.

Barthes, R. (1986). Elements of Semiology (11th print). New York: Hill and Wang.

Barthes, R. (1992). Empire of Signs (10th editi). New York: Hill and Wang.

Bergeaud-Blackler, F. (2015). The halal certification market in Europe and the world: A first Panorama. In F. BergeaudBlackler, J. Fischer, \& J. Lever (Eds.), Halal Matters: Islam, Politics and Markets in Global Perspective (pp.105-126). London and New York: Routledge Taylor and Francis Group. https://doi.org/10.4324/9781315746128-7

Berger, A. A. (2015). Pengantar Semiotika: TandaTanda dalam Kebudayaan Kontemporer (4 edition). Yogyakarta: Tiara Wacana.

Bertels, S., \& Lawrence, T. B. (2016). Organizational responses to institutional complexity stemming from emerging logics: The role of individuals. Strategic Organization (Vol. 14). https://doi.org/10.1177/1476127016641726

Bondestam, F. (2004). Signing up for the status quo? Semiological analyses of sexual harassment in higher education - a Swedish example. Higher Education in Europe, 29(1), 133-145. https://doi.org/10. 1080/03797720410001673346

Christomy, T. (2010). Peircean dan Kajian Budaya. In T. Christomy \& U. Yuwono (Eds.), Semiotika Budaya (pp. 110-143). Depok: Pusat Penelitian Kemasyarakatan dan Budaya, Fakultas Ilmu Pengetahuan Budaya Universitas Indonesia.

Faidah, M. (2017). Sertifikasi Halal di Indonesia: Dari Civil Society menuju Relasi Kuasa Antara Negara dan Agama. Islamica: Jurnal Studi Keislaman, 11(2), 449-476. https://doi.org/https://doi.org/10.15642/ islamica.2017.11.2.449-476

Fiol, C. M. (1989). A Semiotic Analysis of Corporate Language: Organizational Boundaries and Joint Venturing. Administrative Science Quarterly, 34(2), 277-303. https://doi.org/10.2307/2989899

Garrick, B. G., \& Pendergast, D. (2014). The impact of national agenda on a local education authority's website: a visual semiotic analysis. Cambridge Journal of Education, 44(3), 299-317. https://doi.org /10.1080/0305764X.2014.904273

Goodsell,C. T.(1977). Bureaucratic Manipulation of Physical Symbols: An Empirical Study. 
American Journal of Political Science. https:// doi.org/10.2307/2110449

Greenwood, R., Díaz, A. M., Li, S. X., \& Lorente, J. C. (2010). The multiplicity of institutional logics and the heterogeneity of organizational responses. Organization Science, 21(2), 521-539. https://doi. org/10.1287/orsc.1090.0453

Greenwood, R., Raynard, M., Kodeih, F., Micelotta, E. R., \& Lounsbury, M. (2011). Institutional complexity and organizational responses. Academy of Management Annals, 5(1), 317-371. https:// doi.org/10.1080/19416520.2011.590299

Hoed, B. H. (2010). Bahasa dan Sastra dalam Tinjauan Semiotik. In Semiotika Budaya. Depok: Pusat Penelitian Kemasyarakatan dan Budaya, Fakultas Ilmu Pengetahuan Budaya Universitas Indonesia.

Hoed, B. H. (2011). Semiotik dan Dinamika Sosial Budaya. Depok: Komunitas Bambu.

Hosen, N. (2012). Hilal and Halal: How to manage islamic pluralism in Indonesia? Asian Journal of Comparative Law, 7(1), 1-18. https://doi.org/10.1515/1932-0205.1418

Kurland, N. B., \& Aleci, L. S. (2015). From civic institution to community place: the meaning of the public market in modern America. Agriculture and Human Values, 32(3), 505-521. https://doi.org/10.1007/ s10460-014-9579-2

Latif, I. A., Mohamed, Z., Sharifuddin, J., Abdullah, A. M., \& Ismail, M. M. (2014). A Comparative Analysis of Global Halal Certification Requirements. Journal of Food Products Marketing, 20(85), 85-101. https:// doi.org/10.1080/10454446.2014.921869

Lindsey, T. (2012). Monopolising Islam: The Indonesia Ulama Council and State Regulation of the "Islamic Economy." Bulletin of Indonesian Economic Studies, 48(2), 253-274. https://doi.org/https://doi. org/10.1080/00074918.2012.694157
Magnis-Suseno, F. (2019). Etika Politik: Prinsip Moral Dasar Kenegaraan Modern (10th ed.). Jakarta: PT Gramedia Pustaka Utama.

Nafis, M. C. (2019). the Concept of Halal and Thayyib and Its Implementation in Indonesia. Journal of Halal Product and Research, 2(1), 5. https://doi.org/10.20473/ jhpr.vol.2-issue.1.1-5

NU Online. (2020). Cacat Yuridis , PBNU Tolak Monopoli Fatwa MUI pada UU Jaminan Produk Halal. Retrieved February 2, 2020, from https://www.nu.or.id/post/ $\mathrm{read} / 114219 /$ cacat-yuridis--pbnu-tolakmonopoli-fatwa-mui-pada-uu-jaminanproduk-halal ?

Othman, B., Shaarani, S. M., \& Bahron, A. (2016). The potential of ASEAN in halal certification implementation: A review. Pertanika Journal of Social Sciences and Humanities, 24(1), 1-24. Retrieved from http://www.pertanika.upm.edu. my/\%0AReview

Pache, A. C., \& Santos, F. (2010). When worlds collide: The internal dynamics of organizational responses to conflicting institutional demands. Academy of Management Review, 35(3), 455-476. https:// doi.org/10.5465/AMR.2010.51142368

Pasoloran, O. (2016). Narsisisme Dana Aspirasi Masyarakat Dalam Penganggaran Daerah : Kajian Etno-Semiotika. In Simposium Nasional Akuntansi XIX (pp. 1-30). Bandar Lampung: Universitas Lampung, Fakultas Ekonomi dan Bisnis. Retrieved from http://elib.ibs.ac.id/materi/ Prosiding/SNA XIX (19) Lampung 2016/ makalah/106.pdf

Prabowo, S., Rahman, A. A., Rahman, S. A., \& Samah, A. A. (2015). Revealing factors hindering halal certification in East Kalimantan Indonesia. Journal of Islamic Marketing, 6(2), 268-291. https://doi. org/10.1108/JIMA-05-2014-0040 
Rapport, N., \& Overing, J. (2000). Social and Cultural Anthropology: The Key Concepts. Plastic and Reconstructive Surgery (1st ed., Vol. 63). London and New York: Routledge.

Reay, T., \& Hinings, C. R. (2009). Managing the rivalry of competing institutional logics. Organization Studies, 30(6), 629-652. https://doi.org/10.1177/0170840609104803

Saputra, A. (2020). RUU Cipta Lapangan Kerja , Omnibus Law Hapus Kewajiban Makanan Harus Bersertifikat Halal! Retrieved February 3, 2020, from https://news. detik.com/berita/d-4867063/ruu-ciptalapangan-kerja-omnibus-law-hapuskewajiban-makanan-harus-bersertifikathalal $1 / 6$

Soekanto, S. (1989). Sosiologi: Suatu Pengantar. Jakarta: Rajawali Press.

Suharko, S., Khoiriati, S. D., Krisnajaya, I. M., \& Dinarto, D. (2018). Institutional conformance of Halal certification organisation in Halal tourism industry: The cases of Indonesia and Thailand. Tourism, 66(3), 334-348.

Sunardi, S. (2004). Semiotika Negativa. Yogyakarta: Buku Baik.

Thomann, E., Lieberherr, E., \& Ingold, K. (2016). Torn between state and market: Private policy implementation and conflicting institutional logics. Policy and Society, 35(1), 57-69. https://doi.org/10.1016/j. polsoc.2015.12.001

Thornton, P. H., Ocasio, W., \& Lounsbury, M. (2015). The Institutional Logics
Perspective. In Emerging Trends in the Social and Behavioral Sciences. https://doi. org/10.1002/9781118900772.etrds0187

Thornton, P., Ocasio, W., \& Lounsbury, M. (2015). The Institutional Logics Perspective. In Emerging Trends in the Social and Behaviorial Sciences (Vol. 53, pp. 1689-1699).

Viverita, \& Kusumastuti, R. D. (2017). Awareness of halal certification of micro and small enterprises in Jakarta. International Journal of Economics and Management, 11(2 Special Issue), 459-471.

Wahyudi, H., Asikin, Z., \& Haq, H. (2020). Construction of the Legal Framework for Strengthening the Halal Industry in Indonesia. International Journal of Multicultural and Multireligious Understanding, 7(1), 429-438. https://doi. org/http://dx.doi.org/10.18415/ijmmu. v7i1.1321

Wareing, S. (2004). What is language and what does it do? In I. Singhs \& S. Peccei (Eds.), Language, Society and Power: An Introduction (Second, pp. 1-16). London: Routledge.

Widaningrum, A. (2017). Public Trust and Regulatory Compliance. Jurnal Ilmu Sosial Dan Ilmu Politik, 21(1), 1-13. https://doi. org/10.22146/jsp.28679

Zulkifli, Z., \& Mochammad Sahid, M. (2018). Pensijilan Halal: Prosedur dan Implementasi Di Indonesia. Malaysian Journal of Syariah and Law, 8(2), 49-59. https://doi.org/10.33102/mjsl.v6i3.125 